\title{
Notas documentais sobre o Cabo Delgado e Niassa no Século XIX
}

\section{Milton Correia ${ }^{1}$}

Resumo: O presente artigo documenta os fatos históricos ocorridos na segunda metade do século XIX em Cabo Delgado e Niassa no norte de Moçambique. A pesquisa realizada entre os anos de 2010 e 2011 incidiu sobre a documentação dos fundos do governo-geral de Moçambique e do governo do Distrito de Cabo Delgado do Arquivo Histórico de Moçambique (AHM). Constam no artigo os expedientes portugueses referentes a disputa entre Zanzibar e Portugal sobre a fronteira norte de Moçambique em Cabo Delgado e ao Tratado de Comércio e Amizade celebrado entre os dois governos. Constam também expedientes sobre a "Expedição ao Niassa", os diferendos que se desenvolveram entre autoridades portuguesas de Moçambique e autoridades inglesas da África Central Britânica (Niassalândia, hoje Malawi) e sobre as lutas de resistência em Niassa.

Palavras-chave: História de Cabo Delgado e Niassa; Tratado de Amizade e Comércio Portugal-Zanzibar; Expedição ao Niassa; Resistência das Autoridades Yao.

\begin{abstract}
This article documents the historical facts that occurred in the second half of the 19th century in Cabo Delgado and Niassa in northern Mozambique. The research conducted between 2010 and 2011 focused on the documentation of the funds of the general government of Mozambique and the government of the District of Cabo Delgado of the Historical Archive of Mozambique (AHM). The article contains the Portuguese dossiers referring to the dispute between Zanzibar and Portugal on the northern border of Mozambique in Cabo Delgado and the Treaty of Commerce and Friendship between the two governments. There are also files on the "Expedition to Niassa", disputes that have developed between Portuguese authorities in Mozambique and British authorities in British Central Africa (Nyasaland, now Malawi), and on the resistance struggles in Niassa.
\end{abstract}

Keywords: History of Cabo Delgado and Niassa; Treaty of Friendship and Trade PortugalZanzibar; Expedition to Niassa; Resistance of Yao Authorities.

\section{As ilhas de Cabo Delgado, comércio e política}

Por ordem do governador-geral de Moçambique, Joaquim Pereira Marinho, datada de 8 de junho de 1840, a província de Moçambique foi dividida em seis distritos militares: Moçambique, Quelimane, Inhambane, Lourenço Marques, Sofala e Cabo Delgado. ${ }^{2}$

As atenções do governo das Ilhas de Cabo Delgado, sediado na ilha do Ibo, limitavam-se a

1 Pós-graduando no Programa de História Social do Departamento de História da Universidade de São Paulo. Bolsista CNPq/MCT-Mz. E-mail: miltoncorreia@usp.br.

2 AHM. Fundo do Governo do Distrito de Cabo Delgado (séc. XIX). Caixa 8-36. Ordem do dia n 14 do governadorgeral de Moçambique datado de 8 de Junho de 1840. 
assegurar uma presumida e retórica presença portuguesa que na prática era apenas nominal em algumas ilhas deste distrito e circunscrita a algumas áreas da costa da província. ${ }^{3}$ José António Caldas, governador das Ilhas de Cabo Delgado, em ofício enviado em 1824 ao governador e capitão-general de Moçambique, dá conta que Falame Asane, conhecido pelos portugueses por intitular-se rei de Tungue, desenvolvia através do seu porto em Tungue relações comerciais com os pangaios (barcas) árabes, suaíli e franceses. Ele menciona em carta que do volume de fazendas que esses pangaios introduziam na região para troca em bens os mesmos extraiam "todo o comércio das terras". ${ }^{4}$

Segundo o mesmo governador, os navios franceses já em 1823 ancoravam o porto de Tungue. Lamenta que as autoridades portuguesas em Ibo não tinham força capaz de contrapor tal situação porque os franceses vinham "armados de guerra” em prejuízo da presunção de legitimidade e autoridade portuguesas em relação à Tungue. O "cônsul das arábias" no Ibo enviado em representação do governo português para Tungue para reclamar contra a presença de barcas francesas naquele porto ficou a saber do Rei de Tungue que ele "os avia [havia] deademitir [de admitir] porque aquelas terras erão suas e que não pertenciao a nação Portugueza" (sic). ${ }^{5}$

Em janeiro de 1849, Diogo José Fernandes, sargento-mor da ilha de Amiza, Cabo Delgado, vê refutada a execução de uma ordem oficial que emitiu em nome do governo português, mandando Salimo Momade, representante do governo de Zanzibar, que se retirasse do "território portuguez" da ilha de Amiza. Os habitantes desta ilha teriam queixado as autoridades portuguesas de Amiza que Salimo Momade lhes proibira de negociarem com os "Mujãos" (Yao ou Ajaua), permitindo apenas àqueles que lhe pagassem um tributo em forma de taxa comercial. Diogo J. Fernandes reporta ao governador das Ilhas de Cabo Delgado a resposta de Salimo Momade nos seguintes termos: "athe o prezente ignora estas dittas terras haver algum official que faça alguma justiça ou decidir qualquer couza relativo a elle [...] elle não retira destas dittas terras hainda que seja por meio da força."6

Em princípios de 1854, o Iman de Mascate residente em Zanzibar envia uma força que acompanhou a ordem de arvorar a bandeira zanzibarita e cobrar direitos às embarcações nos portos de Tungue e Mineguene, situados na costa de Cabo Delgado. Ao verificarem o sucedido, as autoridades portuguesas designadamente o capitão-mor e comandante de Amiza e o governador das

3 AHM. Fundo do Governo-geral (séc. XIX). Caixa 8-31. Correspondências dos governadores das Ilhas de Cabo Delgado (anos de 1824-1830) ao Governador e Capitão General de Moçambique.

4 AHM. Fundo do Governo-geral (séc. XIX). Caixa 8-31. Ofício de 2 de Março 1824 do Governador das Ilhas de Cabo Delgado José António Caldas ao Governador e Capitão General de Moçambique.

5 AHM. Fundo do Governo-geral (séc. XIX). Caixa 8-31. Ofício de 2 de Março 1824 do Governador das Ilhas de Cabo Delgado José António Caldas ao Governador e Capitão General de Moçambique.

6 AHM. Fundo do Governo do Distrito de Cabo Delgado (séc. XIX). Caixa 8-8. Ofício de Diogo José Fernandes, sargento-mor de Amiza, datado de 27 de Janeiro de 1849 para o governador das Ilhas de Cabo Delgado. 
Ilhas de Cabo Delgado, sediado na vila do Ibo, responsabilizaram ao xeique de Tungue, Momade Bin Sultane, pelo sucedido. Os portugueses suspeitavam que este último teria previamente acordado com o governo de Zanzibar, o que segundo os mesmos se confirmava com o fato dele não ter imposto qualquer resistência que impedisse a execução daquela ordem em defesa das possessões portuguesas de Tungue. ${ }^{7}$

No seu ofício de Agosto de 1858, Luciano Policarpo de Souza sargento-mor em Amiza participa ao governador do Distrito de Cabo Delgado que ele verificava com pesar que nos portos de Quionga, Tungue e Mineguene, onde desde 1854 tremulava a bandeira do Iman de Mascate, negociantes vindos de Zanzibar percorriam por terra as povoações da região violando a autoridade da "nação" portuguesa, porquanto não pagavam direitos das fazendas que importavam, nem dos géneros que obtinham da troca e embarcavam a partir dos referidos portos. ${ }^{8}$

Neste período a baía de Tungue servia como a mais importante placa giratória dos "negócios da terra" na costa ao norte de Cabo Delgado, sobretudo do tráfico de escravos, numa altura em que as autoridades portuguesas no Ibo proibiam este infame negócio. Em fins de agosto de 1854, as autoridades portuguesas no Ibo a luz do decreto de 10 de Dezembro de 1836 impediram que a barca negreira francesa Grognard, procedente de Bourbon, Ilha da Reunião, comprasse e levasse a bordo escravos neste porto. Foi referido que o impedimento foi possível porque a barca não era portadora da autorização de qualquer autoridade portuguesa, não obstante o capitão da barca francesa ter justificado que pretendia estabecer os escravos como colonos ou trabalhadores livres e engajados na Ilha da Reunião. Este parece ter sido um caso isolado de sucesso na execução do decreto antiesclavagista, dado que as mesmas autoridades portuguesas de Ibo por falta de meios militares e navais não foram capazes de impedir que uma outra barca francesa Bombaim nas encostas do rio Musanja (ou Muçanje) comprasse escravos dos moradores de Arimba e mouros de Quiçanga, nem de impedir que os régulos Said Aly e Marere participassem no referido negócio de escravos. ${ }^{9}$ Ao ter sido ordenado que se retirasse por força do decreto de 10 de dezembro de 1836 que estabeleceu que as autoridades portuguesas proibissem a venda de escravos nas possessões ultramarinas seja qual fosse o pretexto, o capitão do Bombaim defendeu-se com a justificação de que aquele distrito não

7 AHM. Fundo do Governo-geral (séc. XIX). Caixa 8-31. Correspondências do governador das Ilhas de Cabo Delgado ao governador-geral de Moçambique datado de 25 de Março de 1854; correspondência do capitão-mor e comandante de Amiza ao governador das Ilhas de Cabo Delgado datado de 24 de Março de 1854; Tradução da carta de Bacar Muchamo, residente em Mineguene datado de 16 de Março de 1854.

8 AHM. Fundo do Governo do Distrito de Cabo Delgado (séc. XIX). Caixa 8-8. Ofício de Luciano Policarpo de Souza, capitão-mor de Amiza, datado de 31 de Agosto de 1858, para o governador do distrito de Cabo Delgado.

9 AHM. Fundo do Governo-geral (séc. XIX). Caixa 8-31. Correspondência do governador das Ilhas de Cabo Delgado datado de 30 de Agosto de 1854 e demais correspondências sobre o assunto incluindo a declaração do capitão do “Grognard” de 30 de Agosto de 1854. As mesmas fontes falam na mesma altura de uma barca francesa „Bombaim“ a comprar escravos naquelas terras. 
pertencia à Coroa portuguesa, para além de também ter declarado que pretendia estabelecer os escravos como colonos ou trabalhadores livres e engajados na Ilha da Reunião. ${ }^{10}$

As fontes consultadas dão indicações que nos anos seguintes as sucessivas entradas de barcas negreiras francesas nas ilhas e rios do Distrito de Cabo Delgado acompanhavam a oferta de escravos na costa cujos mercadores locais operavam fora do alcance das medidas anti-esclavagistas da administração portuguesa, que efetivamente se resumia a vila insular do Ibo. Um dado novo parece ter sido o registro de que em novembro de 1856, uma caravana de 300 a 400 "mujavos" (o mesmo que yao ou ajauas) carregados de marfim esteve na vila do Ibo para negociar. ${ }^{11}$

De outubro a novembro de 1857, foi criada uma comissão para apresentar ao chefe Mugabo, cujas terras estavam situadas nas margens da baía de Pemba, a carta do governador de português no Ibo, Jerónimo Romero, na qual este manifestava o desejo de estabelecer nos termos de amizade e aliança a primeira colónia de moradores portugueses na parte continental do Distrito de Cabo Delgado, oferecendo em troca a atribuição de uma graduação militar e um ordenado mensal ao referido chefe local. ${ }^{12}$ Em carta datada de 17 de novembro de 1857, o chefe Mugabo aceita a proposta de "amizade e aliança"13. Mas ao contrário do teor da carta em que o chefe Mugado aceita o estabelecimento de relações de amizade e aliança, acabaria por ser lavrado um termo constando que o referido chefe local aceitava a vassalagem aos portugueses:

[...] que estas terras do Reglo Mugabo e de todo a sua gente ficarão reconhecidas como pertencentes a Coroa de Portugal e todos os indivíduos e indigenas ou não indigenas ficarão súbditos obdientes e cidadãos portugueses,= Que os Reglos Mugabo lhe sera concedido pelo governo de Sua Majestade ElRei o posto de Capitão Môr das terras de Mugabo. ${ }^{14}$

Em dezembro de 1881, a alfândega do Distrito de Cabo Delgado registra, em relação ao movimento comercial de 1880, que os artigos coloniais em que se realizaram maiores transações,

10 AHM. Fundo do Governo-geral (séc. XIX). Caixa 8-31. Correspondência do patrão-mor do porto de Ibo ao governador das Ilhas de Cabo Delgado datado de 24 de Outubro de 1854. Ver as demais correspondências sobre o assunto.

11 AHM. Fundo do Governo-geral (séc. XIX). Caixa 8-31. Correspondência do governador das Ilhas de Cabo Delgado para o governador-geral da Província de Moçambique datada de 9 de Dezembro de 1856.

12 AHM. Fundo do Governo-geral (séc. XIX). Caixa 8-31. Ofícios do governador das Ilhas de Cabo Delgado para o régulo Mugabo datados de 27 Outubro e 12 de Novembro de 1857.

13 AHM. Fundo do Governo-geral (séc. XIX). Caixa 8-31. Carta do Régulo Mugabo ao governador das Ilhas de Cabo Delgado datada de 17 de Novembro de 1857.

14 AHM. Fundo do Governo-geral (séc. XIX). Caixa 8-31. Termo de relações entre o governo português no Ibo e o régulo Mugabo, em que este último aceitava o estabelecimento de colonos portugueses num terreno dos seus domínios na Baía de Pemba, datado de 17 de Novembro de 1857. Os colonos portugueses viriam imediatamente a ser assentados em Muquete nas terras do régulo Marere, nas margens da baía de Pemba. Ver também Termo de constituição da colónia datado de 8 de Dezembro de 1857. 
como de costume, foram gergelim, cauril, cera, gomas, marfim, milho fino, arroz, tartaruga, cujos maiores mercados consumidores foram Marselha, Bombaim e Zanzibar. Na importação, os que mais avultaram foram o algodão cru, branco, estampado, tinto em peça ou em fio, pólvora, armas, manteiga da Índia transacionados de Bombaim, Zanzibar, Marselha, Cardiff, Hamburgo, constando que não houve comércio com a metrópole, nem com nenhuma das ilhas adjacentes ou outras províncias ultramarinas portuguesas. ${ }^{15}$

Segundo a mesma fonte, a entrada do marfim do interior no ano de 1880 contribuiu para o aumento de rendimento da alfândega em relação ao ano transacto, sem no entanto se referir ao peso deste artigo em relação aos demais referidos acima. Nos anos anteriores o marfim afluiu mais para os distritos do sul, provavelmente o Distrito de Moçambique, e aponta como certo que o marfim teria concorrido muito mais para o rendimento desta alfândega "se não tivesse transitado pelo alto certão para os domínios de Sua Alteza o Sultão de Zanzibar, por ser para ali o transito mais facil às tribus d'alem do Nyasa, segundo se me afirma." (sic) ${ }^{16}$ Entretanto, não estão identificados os mercadores deste marfim para além desta única referência às tribos do Niassa.

Segundo o diretor desta casa fiscal sediada na ilha do Ibo, a construção de estradas partindo de pontos mais importantes do litoral como Lúrio, Pemba, Quissanga, Pangane, para o interior do sertão "ao menos ate uma distancia de 30 a 40 kilometros communicando entre si por meio d'uma outra que as unisse, pelo menos nos seus extremos internos", bem como a navegação a vapor ao invés da navegação a favor do vento das monções, contribuiriam para a facilidade no transportes dos produtos do interior com efeitos benéficos para as transações e movimento comercial no Distrito de Cabo Delgado. ${ }^{17}$

Em dezembro de 1887, ao reportar a ocupação colonial de Tungue efetuada em fevereiro deste ano, o diretor da alfândega do Ibo viu a ocasião para insistir no assunto de estradas. Era de seu entendimento que feita a referida ocupação, a construção de uma estrada neste ponto situado a norte do litoral do Distrito de Cabo Delgado abriria vias de fácil comunicação entre o sertão e a baía de Tungue que "facilitaria a exportação de generos agriculas que, hoje, não podem ser conduzidos aos mercados do litoral por não comportarem despezas de transporte". Com a falta de vias de acesso não só seria impossível a exportação em larga escala e, por conseguinte, uma maior amplitude das transações de troca de bens com os mercadores do interior, bem como seria também impossível a

15 AHM. Fundo do Governo-geral (séc. XIX). Caixa 8-179. Ofício do diretor da Alfândega do Distrito de Cabo Delgado, 9 de Dezembro de 1881.

16 Ibid.

17 AHM. Fundo do Governo-geral (séc. XIX). Caixa 8-179. Ofício do diretor da Alfândega do Distrito de Cabo Delgado, 9 de Dezembro de 1881. 
penetração colonial do litoral até aos "reconditos do sertão; e, desse facto não só adviriam vantagens commerciais, mas tambem politicas." 18

Nesta ocasião insiste também na importância que uma estrada teria para capitalizar a riqueza existente no interior em benefício da alfândega do Ibo, contra o que vinha acontecendo com o vizinho Zanzibar, ao sair de um

[...] ponto qualquer comprehendido entre a povoação da Quissanga e a margem sul da bahia de Pemba, para o alto sertão e atravez do paiz de Mêdo, teriamos assegurado aos nossos estabelecimentos, todo o commercio da vasta região que se estende ao sul do Rovuma entre o Nyassa e o litoral do Distrito. Nestas condições, a fiscalização seria facil, porque sendo a pauta menor do que a de Zanzibar, não seriamos nós que deveriamos temer o contrabando, nem tam pouco conviria aos interessados subtrair as mercadorias ao pagamento de um imposto ainda mais moderado do que o actual." (sic) ${ }^{19}$

Não se tratava de uma nova questão, dado que anteriormente em dezembro de 1881 o diretor das obras públicas da província de Moçambique, António José, manifestara ao governador do Distrito de Cabo Delgado o desejo de aproveitar a sua permanência neste distrito para internar pelo continente e fazer um primeiro reconhecimento e estudos precisos para a construção de uma estrada que passando pela povoação do Medo se dirigiria para o lago Niassa. ${ }^{20}$

\subsection{Disputa fronteiriça entre Portugal e Zanzibar}

Em dezembro de 1861, em conformidade com as ordens e instruções da Sua Majestade expedidas em portaria $\mathrm{n}^{\circ} 18$ de 1861, Portugal tentou sem sucesso por intermédio do seu governador-geral em Moçambique, João Tavares de Almeida, inserir no Tratado de Amizade e Comércio assinado com o sultão de Zanzibar Said Magid Bin Said o seguinte artigo que situaria no ponto de $10^{\circ} 40^{\prime}$ latitude sul a linha de demarcação de fronteira que ao norte limitaria Moçambique dos estados de Zanzibar:

The High contracting Parties have agreed to declare that the territories of His Highness the Sultan of Zanzibar upon the East Coast of Africa shall end in Cape Delgado situated in about $10^{\circ} 40^{\prime}$ Lat. S. and that the territories of His Majesty the

18 AHM. Fundo do Governo-geral (séc. XIX). Caixa 8-179. Ofício do diretor da alfândega do Ibo de 10 de Dezembro de 1887 para o governador-geral de Moçambique.

19 AHM. Fundo do Governo-geral (séc. XIX). Caixa 8-179. Ofício do diretor da alfândega do Ibo de 10 de Dezembro de 1887 para o governador-geral de Moçambique.

20 AHM. Fundo do Governo do Distrito de Cabo Delgado (séc. XIX). Caixa 8-36. Ofício do diretor das obras públicas de Moçambique datado de 2 de Dezembro de 1881 para o governador de Cabo Delgado. 
King of Portugal upon the same coast commence in the said cape including the Bay of Tungue. ${ }^{21}$

Com a tentativa de inclusão desta cláusula no tratado, João Tavares de Almeida procurou em Zanzibar justificar em duas vertentes o direito de Portugal sobre a região ao sul do rio Rovuma que incluiria toda a baía de Tungue. A primeira vertente era de que Portugal teria em 28 de julho de 1817 acordado em Londres com a Grã-Bretanha o reconhecimento de Cabo de Delgado e inclusivamente de Tungue nas possessões portuguesas de Moçambique. Nas negociações anteriores ao projeto do tratado com Zanzibar já constava que os limites dos domínios portugueses na costa oriental da África incluiriam a baia de Tungue. Já antes em 1828 e 1854, os predecessores de João Tavares de Almeida, os governadores-gerais Sebastião Xavier Botelho e Joaquim Pinto de Magalhães, respetivamente, em missões diplomáticas em Zanzibar junto do Rei Said de Mascate não foram capazes de obter a ratificação deste tratado devido, segundo as declarações do plenipotenciário do sultão de Zanzibar, ao desacordo em torno de uma cláusula dos portugueses que não incluía a baía de Tungue dentro das possessões dos estados de Zanzibar. ${ }^{22}$

Noutra vertente, João Tavares de Almeida justificava junto do sultão Said Magid Bin Said em Zanzibar esta afirmação de direito sobre a baía de Tungue no facto do anterior xeique em Tungue ter antes de 1854 arvorado a bandeira portuguesa e recebido um soldo pago pela feitoria do Ibo, o que as autoridades portuguesas entendiam como "prova evidente de que se reconhecia subdito e servidor portuguez". ${ }^{23}$

Refutando as justificações de direito expostas pela parte portuguesa, o sultão de Zanzibar Said Magid Bin Said declarou como limite sul dos seus estados o rio Mirenene, reafirmando que a povoação de Tungue e o Cabo Delgado pertenciam ao seu território. Na realidade, ao contrário dos portugueses, Zanzibar já havia em 1854 estabelecido na povoação de Tungue, bem ao sul da latitude de Cabo Delgado e da latitude $10^{\circ} 40^{\prime} \mathrm{S}$ uma delegação de alfândega e guarnição. ${ }^{24}$ Como vimos acima registros portugueses referentes a este período do ano de 1854 reconhecem e lamentam que a afirmação de posse portuguesa sobre Tungue nunca passou de nominal.

21 AHM. Fundo do Governo-geral (séc. XIX). Caixa 8-151. Cópia do ofício do governador-geral de Moçambique João de Tavares de Almeida, de 8 de Fevereiro de 1862 que acompanhou o tratado de amizade e comercio com o sultão de Zanzibar.

22 Ibid.

23 AHM. Fundo do Governo-geral (séc. XIX). Caixa 8-151. Cópia do ofício do governador-geral de Moçambique João de Tavares de Almeida, de 8 de Fevereiro de 1862 que acompanhou o tratado de amizade e comercio com o sultão de Zanzibar.

24 Ibid. Veja-se o mapa contendo o limite proposto pelo plenipotenciário português João Tavares de Almeida (o ponto $10^{\circ} 40^{\prime}$ Lat. S.) e a declaração de limite feita pelo sultão de Zanzibar (o rio Mirenene). 
Sankofa. Revista de História da África e de Estudos da Diáspora Africana Ano IX, NXVIII, dezembro/2016

Localizaçao geográfica dos limites propostos por Portugal e Zanzibar

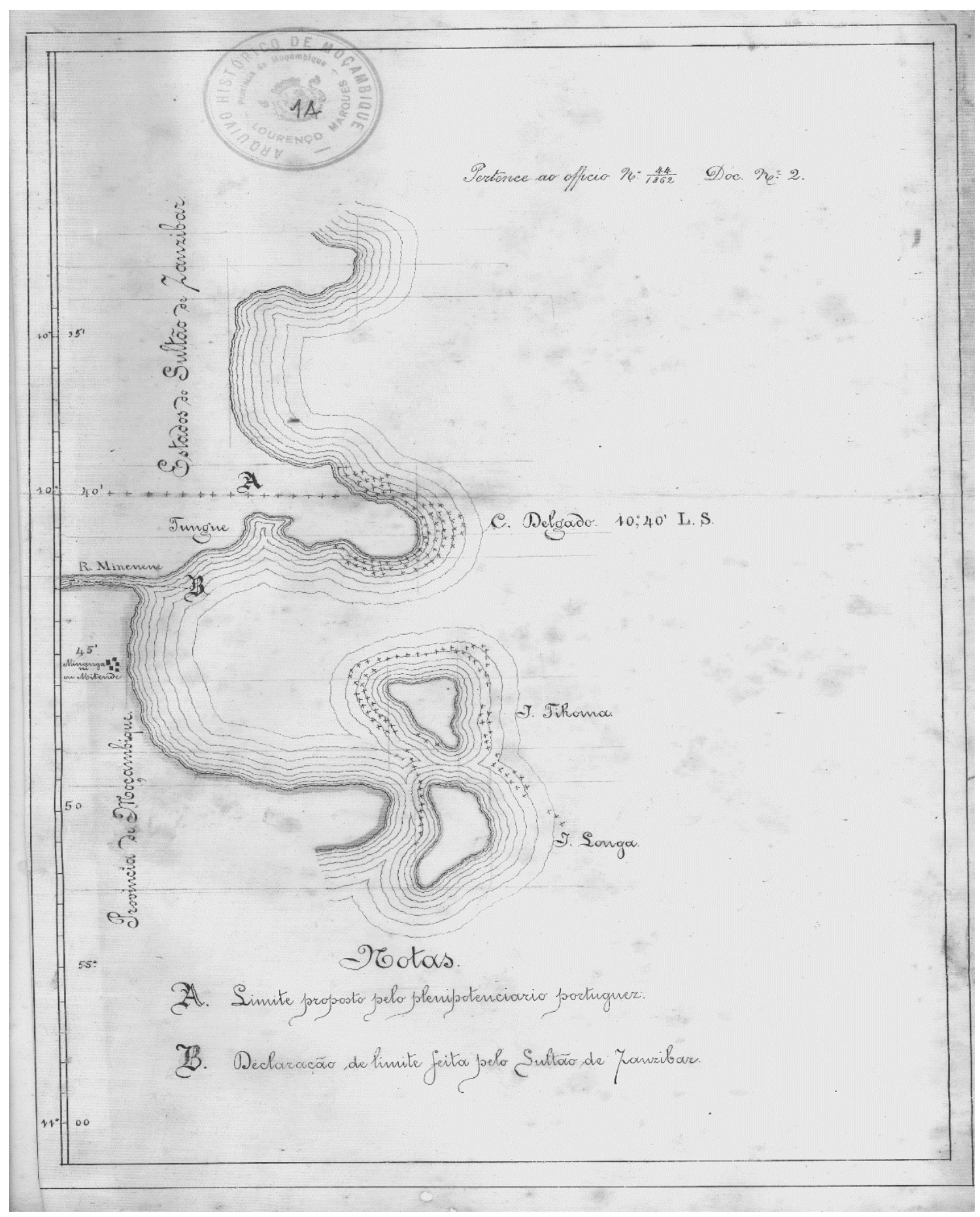

AHM. Fundo do Governo-geral (séc. XIX). Caixa 8-151. Cópia do ofício do governador-geral de Moçambique 
João de Tavares de Almeida, de 8 de Fevereiro de 1862 que acompanhou o tratado de amizade e comercio com o sultão de Zanzibar.

Em outubro de 1879, o governador-geral de Moçambique, Francisco Maria da Cunha, a fim de ratificar e com isso concluir este processo do tratado de amizade e comércio com Zanzibar voltou a insistir, sem êxito, na questão dos limites desta feita com o novo sultão Said Barghash Bin Said Bin Sultan Bin Ahmad, que defendendo a declaração do antigo sultão Said Magid Bin Said rejeitou a mesma afirmação portuguesa de limite segundo a cláusula de 1861. Finalmente, a 25 de Outubro de $1879^{25}$ é assinado o tratado de amizade e comércio entre Portugal e Zanzibar sem a cláusula de limites, cuja ratificação viria a ser celebrada a 18 de Junho de 1883, tendo a parte portuguesa sido representada pelo seu plenipotenciário capitão-de-fragata Gregório José Ribeiro. ${ }^{26}$

Na sequência deste diferendo sobre os limites entre a Sua Alteza de Zanzibar e Portugal, em dezembro de 1885 e janeiro de 1886 duas canhoneiras portuguesas Quanza e Vouga da Divisão Naval d'África e Mar da Índia foram enviadas por ordem do governador-geral em Moçambique, Augusto de Castilho, com instruções de efetuar o desembarque de forças portuguesas "a bem ou mal" na foz do rio Meningane e ocupar militarmente e por meio de um posto fiscal a sua margem direita. O objetivo do desembarque das praças e as instruções dadas ao capitão Ludovico de Sousa e Brito, a quem foi encarregado o posto de ocupação de Meningane, e ao comandante da canhoneira Quanza estavam claros: deveriam arvorar a bandeira portuguesa, montar a guarnição das posições estratégicas com vista a defender o ponto de embarque e da água potável, estabelecer o posto fiscal, regularizar o comércio nesse ponto, estabelecer de imediato um correio terrestre entre o posto de ocupação em Meningane e a vila do Ibo. ${ }^{27}$

A presença das forças naval e terrestre portuguesa nas águas da baía de Tungue respondia ao estado de tensão que tomava conta do governo português, quer da parte do governador-geral na altura, Augusto de Castilho, quer do cônsul geral português em Zanzibar, e ainda do Ministro da Marinha que a partir de Lisboa encetava negociações junto das autoridades britânicas para a intermediação a favor de Portugal no diferendo sobre limite entre Moçambique e Zanzibar. ${ }^{28}$ Até

25 AHM. Fundo do Governo-geral (séc. XIX). Caixa 8-151. Cópia do ofício de Francisco Maria da Cunha plenipotenciário na assinatura do tratado de amizade e comércio com Zanzibar, datada de 1 de Dezembro de 1879 (veja-se o também o referido tratado).

26 AHM. Fundo do Governo-geral (séc. XIX). Caixa 8-151. Ofício de Gregório José Ribeiro datado de 27 de Junho de 1883.

27 AHM. Fundo do Governo do Distrito de Cabo Delgado (séc. XIX). Caixa 8-36. Ofícios do governador-geral de Moçambique datados de 13 e 14 de Janeiro de 1886 ao comandante da divisão naval d'África e mar da Índia; Esboço de instruções dadas ao comandante da canhoneira „Quanza“ em comissão a desempenhar na costa norte de Moçambique.

28 Ibid. 
fins de janeiro de 1886 foi pacífica a ocupação portuguesa da margem sul da foz do rio Meningane na baía de Tungue. ${ }^{29}$

\section{Expedições, tratados e invasão colonial em Niassa}

Foi ao comando do seu subchefe, Augusto de Mello Pinto Cardoso, que a expedição científica "Pinheiro Chagas", oficialmente encarregada ao cônsul geral de Portugal em Zanzibar, Serpa Pinto, alcançou depois de uma paragem em Quissanga de quase todo o ano de 1885 aqueles que nos parecem os primeiros feitos portugueses na região do Niassa com a declaração de vassalagem do Metarica nas margens do rio Lugenda em dezembro deste ano e do Cuirassia em janeiro de 1886 na extremidade sul do lago Niassa. ${ }^{30}$

Segundo a referida declaração estes chefes obrigavam-se desde o momento do auto de vassalagem a prestar todo o auxílio em mantimentos e carregadores a qualquer viajante português que no futuro atravessasse os seus territórios destes chefes, obedecer às ordens das autoridades portuguesas e estabelecer uma relação pacífica com a presença portuguesa. Particularmente ao chefe Metarica, Augusto Cardoso recomenda que ele deveria pôr termo aos "constantes" ataques dos seus súbditos Mafites contra Quissanga. Da declaração consta também que o Metarica enviaria uma embaixada ao Ibo para renovar a sua obediência à Portugal diante do governador do Distrito de Cabo Delgado. Essa embaixada seria acompanhada por um certo número de Mafites, súbditos do Metarica, para "quebrar as zagaias e rodelas" simbolizando a prova do fim dos assaltos. O Cuirassia deveria enviar a sua embaixada à Quelimane com o mesmo objetivo. ${ }^{31}$

Luiz Augusto Machado Leal encarregado da "missão civilizadora ao lago Nyassa", acompanhado de uma força de cipais, volta a receber na povoação do Cuirassia por intermédio de uma embaixada o idêntico juramento de vassalagem pelo qual o Cuirassia de nome Chercuácua bin Maginde afirma defender a bandeira portuguesa em junho de $1889 .{ }^{32}$

Em junho de 1891 a missão portuguesa Mariano de Carvalho, expedição ao rio Lugenda e ao sul do rio Rovuma, chefiada por José Gonçalves Barriga, comandante militar de Palma, com

29 AHM. Fundo do Governo do Distrito de Cabo Delgado (séc. XIX). Caixa 8-36. Ofício do comandante da canhoneira „Vouga“ datado de 30 de Janeiro de 1886 ao governador do distrito de Cabo Delgado.

30 AHM. Fundo do Governo do Distrito de Cabo Delgado (séc. XIX). Caixa 8-36. Ofício de Augusto Cardoso subchefe encarregado da expedição „Pinheiro Chagas“ datado de 18 de Dezembro de 1885 ao governador do distrito de Cabo Delgado (vide também o auto de vassalagem do Metarica datado de 16 de Dezembro de 1885 e o de Cuirassia datado de 20 de Janeiro de 1886);

31 Ibid.

32 AHM. Fundo do Governo do Distrito de Cabo Delgado (séc. XIX). Caixa 8-36. Ofício de Luiz Augusto Machado Leal encarregado da „missão civilizadora ao lago Nyassa“ datado de 11 de Junho de 1889 ao governador do distrito de Cabo Delgado; Termo de vassalagem do régulo Cuirassia de 11 de Junho de 1889. 
destino a Itulle, norte do rio Lugenda, onde deveria realizar a sondagem de um jazigo de carvão de pedra para se conhecer a sua qualidade e quantidade, surpreendeu-se ao tomar conhecimento de ter sido antecedida pela expedição de dois súbditos alemãs saídos de Quíloa acompanhada por uma força armada. Em presença desta força alemã e em vista da bandeira alemã que os dois súbditos alemães levavam em Itulle, José Gonçalves Barriga achou-se mesmo obrigado a justificar-se com base nos termos da convenção de fronteira luso-alemã de 1886, que estabeleceu o rio Rovuma como o limite entre a área de influência portuguesa, ao sul, e alemã, ao norte. A expedição portuguesa que iniciou o percurso Palma-Quionga e internou pela região do Rovuma esteve muito dependente de carregadores de Quionga contratados por dois negociantes, Massude e Bacar, suspeitos pelo chefe desta expedição de manter contactos pouco claros com os alemães em Mikindane acerca dos jazigos de carvão em Itulle. ${ }^{33}$

Para o chefe desta expedição portuguesa, o incidente de Itulle realçou a urgência para a ocupação efetiva da área de influência portuguesa coberta pelo acordo luso-germânico de 1886, tendo nessa ocasião recomendado para que fosse estabelecida até Itulle comandos militares em Coamuno, Liture, Ingomano e outros em número total de seis que para além de assegurar a soberania portuguesa servissem de estações tanto para o Itulle como de estrada que asseguraria fontes de receitas aos cofres portugueses tanto que havia indicações de ser por esse "caminho que todas as caravanas, tanto do Nyassa como d'outros pontos do sertão trilham até chegarem a Mekindane, Palma, Mossimbõa e Quissanga." 34 Itulle continuou no centro das atenções, tanto que H. Copeland, "general-manager" e diretor em África para a Companhia do Nyassa, saiu de Pemba para o interior em novembro de 1893 com a intenção de atravessar o Medo e seguir para Itulle. ${ }^{35}$

Desde o início de atribuição da concessão em 1892, que os alemães constituíam uma interrogação para a direção da Companhia do Nyassa, sediada na vila do Ibo. Pouco depois de H. Copeland ter participado em junho de 1894 ao governador do Distrito de Cabo Delgado que se retirava para Europa e deixava a cargo de Arthur C. Wheatley todos os negócios desta companhia em África, este último pede ao governador deste distrito explicações em torno das informações segundo as quais os alemães haviam levantado bandeira alemã em Quionga e Palma, dentro do território da concessão da Companhia de Nyassa. ${ }^{36}$

33 AHM. Fundo do Governo do Distrito de Cabo Delgado (séc. XIX). Caixa 8-36. Ofício de José Gonçalves Barriga, comandante da missão Mariano de Carvalho - expedição ao Lugenda e sul do Rovuma, datado de 16 de Junho de 1891 ao governador do distrito de Cabo Delgado.

34 Ibid..

35 AHM. Fundo do Governo do Distrito de Cabo Delgado (séc. XIX). Caixa 8-16. Ofício da Companhia do Nyassa no Ibo para o governador de Cabo Delgado datado de 26 de Dezembro de 1893.

36 AHM. Fundo do Governo do Distrito de Cabo Delgado (séc. XIX). Caixa 8-16. Ofício de H. Copeland generalmanager e diretor em África para a Companhia do Nyassa datado de 13 de Junho de 1894 para o governador do 
Com a entrega dos haveres do estado português pelo até então governador interino do Distrito de Cabo Delgado, Caetano Joaquim Fialho dos Reis, ao intendente nomeado pelo decreto de 22 de Novembro de 1894, capitão António Ferreira de Carvalho, ficou oficialmente instalada a intendência do Ibo junto da Companhia do Nyassa em 19 de dezembro de 1894. Passando a intendência do Ibo a representar o estado português no interior do território de Cabo Delgado e Niassa, concedido à Companhia do Nyassa. ${ }^{37}$

Não estando ainda certo dos factos, o intendente do governo interino no Ibo chegou a participar em julho de 1896 ao governador-geral de Moçambique as informações que corriam, uma das quais obtidas do chefe de Quissanga, Buana xeique Bin Abdul Latife, segundo as quais duas expedições alemães, uma saída de Lindi e outra de Mikindani ou Quionga, em meados deste ano haviam atravessado para o Niassa. Opinando sobre as mesmas informações dando conta que no seu trânsito teria havido confrontos nas terras do interior, este intendente do governo admitiu a possibilidade dos confrontos terem ocorrido nas terras do Mataca, "pelo facto deste regulo se oppôr sempre à passagem de caravanas em que vão europeus." ${ }^{n 38}$

Pouco depois em agosto deste ano, uma caravana (no entanto não indicada a sua proveniência) vinda do interior carregada de marfim para trocar por armas e pólvora ${ }^{39}$ teria informado que não houve passagem de nenhuma expedição alemã pelo território da concessão, mas que o chefe Cuirassia havia sido batido pelos ingleses da Niassalândia na fronteira com Milanje, tendo-se refugiado muita da sua gente nas terras do Mataca. ${ }^{40}$

Nesta altura de fins de julho de 1896, surgem suspeitas de divisões no seio da direção da Companhia do Nyassa. O governador do território da Companhia do Nyassa, Joaquim Sanchez Rollão Preto, não confirma as suspeitas mas manifesta semelhantes preocupações levantadas pelo intendente do governo interino no Ibo. Joaquim S. R. Preto declara como sendo fraudulenta uma procuração que teria sido submetida na conservatória do Ibo por um indivíduo identificado como

distrito de Cabo Delgado; Ofício de Arthur C. Wheatley administrador da Companhia do Nyassa datado de 10 de Julho de 1894 para o governador do distrito de Cabo Delgado.

37 AHM. Fundo do Governo-geral (séc. XIX). Caixa 8-179. Ofício do intendente do governo no Ibo ao governadorgeral da Província de Moçambique de 21 de Dezembro de 1894 e incluso o respetivo auto de entrega dos haveres do estado.

38 Ibid. Ofício do intendente do governo interino no Ibo ao governador-geral da Província de Moçambique de 9 de Julho de 1896.

39 Esta caravana teria depois desviado parte dos artigos para troca para a colónia alemã por força da proibição da venda de armas, pólvora e escravos imposta pelo governo português. A ausência de registros oficiais por parte das autoridades coloniais na vila de Ibo sobre as caravanas de marfim e escravos vindas do interior para troca parece estar associada com a ordem de proibição de tráfico negreiro e importação de armas e pólvora. Sobre o decréscimo do movimento comercial na alfândega do Ibo ver os ofícios do intendente do governo interino no Ibo ao governador-geral da Província de Moçambique de 9 de julho 1896 e 13 de Dezembro de 1896.

40 AHM. Fundo do Governo-geral (séc. XIX). Caixa 8-179. Ofício do intendente do governo interino no Ibo ao governador-geral da Província de Moçambique de 20 de Agosto de 1896. 
sendo um súbdito francês de nome Anteroche. Parece que este indivíduo apresentou-se como representante de um grupo do conselho de administração desta companhia que estaria a reivindicar em nome de um grupo de acionistas "todos os direitos á concessão que, pelos respectivos decretos, pertencem áquella companhia,- como o usufruto dos terrenos, propriedades, bens, direitos, acções e mais prerrogativas que compõem a mesma concessão". (sic $)^{41}$

O intendente do governo português no Ibo atribui às divisões internas no seio da direção da Companhia do Nyassa na Europa a causa por que até então não via iniciativa de trabalhos no plano de desenvolvimento nos territórios da concessão. Ele manifestava-se insatisfeito pelo facto de até a data desde a atribuição da carta de concessão em 1891 e tomada de posse dos territórios em $1894^{42}$ as atividades da Companhia de Nyassa limitavam-se a uma fixação provisória na vila do Ibo, onde a companhia tinha instalado sua sede, vivendo do rendimento da alfândega do Ibo, dos postos fiscais de Tungue, Quissanga, Mocímboa e do correio. A sua insatisfação decorria do facto de que estas áreas do território da concessão já se encontravam previamente ocupadas pelo antigo governo distrital de Cabo Delgado antes da concessão. ${ }^{43}$

Num ofício do governador dos territórios da Companhia do Nyassa, João M. Guerreiro d'Amorim, datado de 8 de junho de 1898, é mencionado que o capitão do exército francês Loynes d'Anteroche, empregado desta companhia, teria sido bem recebido pelo Mataca numa missão de estudo que ele efetuou ao Niassa em $1896 .{ }^{44}$ Loynes d'Anteroche relata as suas observações sobre a situação política no Niassa, e adverte ao governador-geral de Moçambique sobre as investidas dos ingleses em relação ao traçado de demarcação da fronteira anglo-portuguesa na região do lago Niassa e as ameaças que essas investidas representavam para o território português e principalmente para a área da concessão da Companhia do Nyassa se prevalecesse a ausência de iniciativas da parte portuguesa. ${ }^{45}$ Do relato de d' Anteroche transmitido ao governador da Companhia de Nyassa, João Guerreiro d'Amorim, constava que Mataca mantinha sob seu domínio um vasto território na margem oeste do rio Lugenda, em Niassa, com terrenos riquíssimos e muito agricultados, possuindo grande quantidade de marfim, sendo por isso um dos mais importantes "regulos" dos territórios de

41 Ibid. Ofício do governador do Território da Companhia do Nyassa ao intendente do governo no Ibo de 24 de Julho de 1896.

42 MINISTÉRIO DA MARINHA E ULTRAMAR. Companhia do Nyassa: Decretos, Portarias, Regulamentos e Mais Diplomas relativos a esta companhia. Lisboa: Imprensa Nacional, 1897 (ver Decreto de 26 de Setembro de 1891).

43 AHM. Fundo do Governo-geral (séc. XIX). Caixa 8-179. Ofício do intendente do governo no Ibo ao governadorgeral da Província de Moçambique de 27 de Julho de 1896.

44 AHM. Fundo do Governo-geral (séc. XIX). Caixa 8-180. Ofício do governador dos Territórios da Companhia do Nyassa, de 8 de Junho de 1898, para o governador-geral da Província de Moçambique.

45 AHM. Fundo do Governo-geral (séc. XIX). Caixa 8-180. Cópia do ofício de 6 de Junho de 1898 do Senhor Loynes d'Anteroche feita no governo dos Territórios da Companhia do Nyassa, no Ibo, de 8 de Junho de 1898 e enviada ao governador-geral de Moçambique. 
Cabo Delgado. Sendo apontado que o chefe Mataca constituía o foco das atenções dos concorrentes ingleses do Niassalândia que, segundo a mesma fonte, pretendiam batê-lo mais para espoliá-lo, do que para o castigar pelos crimes e razias que lhe atribuíam. ${ }^{46}$

Segundo o mesmo relato de d'Anteroche reportado ao governador-geral de Moçambique, Mataca teria à sua disposição para além de um exército forte e temido de soldados disciplinados, uniformizados e armados com armas Snyder, um território sob seu domínio bastante povoado onde poderia dispor-se de inúmero efetivo em caso de guerra. Relativamente à alegada hostilidade que Mataca mantinha em relação aos brancos, segundo a mesma fonte, resultava das perseguições dos ingleses que teria mesmo forçado à que este potentado do interior em 1897 enviado um pedido de perdão ao governo português, manifestando o desejo de prestar vassalagem. Capitão d'Anteroche adverte ao governador-geral de Moçambique sobre a relação estratégica que o governo português deveria desenvolver com o Mataca diante das incursões inglesas na região do lago Niassa, tendo em conta a condição favorável que ela representaria para o governo da Companhia do Nyassa. D' Anteroche reconhecia que a estabilidade da presunção de soberania portuguesa na região de Niassa, sobretudo a faixa entre o rio Lugenda, lago Niassa e a fronteira com a Niassalândia, era devida a resistência imposta pelo Mataca contra as investidas inglesas, porquanto crê "que é devido ao receio que têm d'ele, que os inglezes ainda não occuparam os territórios entre o Nyassa e o Lugenda". ${ }^{7}$

Je crois donc, Monsieur le Gouverneur que l'interêt du Gouverneurment Portugais et surtout de la Compagnie du Nyassa est donc de proteger Mataka et non de l'attaquer, puisque, comme j'ai essajé de vous le demontrer c'est grace à luir que la partie entre Ludjenda et Nyassa est encore portugaise. (sic) ${ }^{48}$

Por fim, d' Anteroche sugere que na eventualidade de se levar a cabo uma penetração colonial portuguesa para o interior do território do Mataca a partir da linha Ibo-Quiçanga, o governo português poderia percorrer o "caminho de preto" no período entre o mês de junho e o início da época das chuvas, que inicia em novembro, seguindo um trajeto de cerca de 18 ou 20 dias, contando que na maioria dos casos a região era inacessível para carros. ${ }^{49}$

Esta missão de d'Anteroche não foi a única a percorrer no âmbito das atribuições da

46 AHM. Fundo do Governo-geral (séc. xix). Caixa 8-180. Ofício do governador dos Territórios da Companhia do Nyassa, de 8 de Junho de 1898, para o governador-geral da Província de Moçambique.

47 AHM. Fundo do Governo-geral (séc. XIX). Caixa 8-180. Ofício do governador dos Territórios da Companhia do Nyassa, de 8 de Junho de 1898, para o governador-geral da Província de Moçambique.

48 AHM. Fundo do Governo-geral (séc. XIX). Caixa 8-180. Cópia do ofício de 6 de Junho de 1898 do Senhor Loynes d'Anteroche, Ibo, 8 de Junho de 1898 e enviada ao governador-geral de Moçambique.

49 Ibid. 
Companhia do Nyassa o território da concessão. Consta que antes dela, por conta de um sindicato inglês, exploradores Howard e Copeland teriam descoberto jazigos de ferro magnético, carvão grafite, ouro de aluvião junto ao rio Lugenda no Niassa. Consta ainda que em março de 1895 a missão do engenheiro inglês Arthur Wheatley a mando da Companhia do Nyassa teria sido incumbida de estudos de reconhecimento do porto de Pemba e do caminho-de-ferro para o Mêdo para daí ligar ao lago Niassa. Esta missão não terá ido para além do Metarica, junto ao rio Lugenda, porque os carregadores ou pessoal da expedição que a acompanhava, em pequeno número, terem recusado avançar para os territórios do Mataca. ${ }^{50}$

\section{1. "Expedição ao Nyassa" (1899)}

Ao nível do Estado-Maior de Moçambique, em Lourenço Marques, já vinha sendo preparada desde maio de 1899 sob direção do Major Manoel de Sousa Machado a denominada “expedição ao Nyassa”. Neste âmbito foi o governador da Companhia do Nyassa questionado em novembro de 1898 sobre as incursões dos Yao contra os territórios ingleses, tendo respondido que não sabia de nada ultimamente, mas se tivessem acontecido, tanto quanto foi reportado por d'Anteroche, elas só poderiam resultar de provocações dos ingleses que por mais de uma vez vinham hostilizando os "regulos" do território português. ${ }^{51}$

Ainda em maio foi preparada uma portaria para proibir nos territórios administrados pela Companhia do Nyassa (Niassa e Cabo Delgado) e noutros distritos e áreas de concessão a importação de pólvora e armas nos casos em que os respectivos governadores tivessem certeza absoluta que os mesmos poderiam destinar-se aos povos não avassalados e hostis aos seus governos. $^{52}$

Nas instruções para a "expedição ao Nyassa" assinadas pelo governador-geral de Moçambique, Álvaro da Costa Ferreira, constava a determinação para reduzir à obediência das autoridades portuguesas os povos que até então só reconheciam a autoridade política do Chefe Mataca e de chefaturas que deste dependiam, em especial Cuamba, Catuli e Zafari. Devendo a expedição, se possível, prender estes chefes assim como aos demais a estes subordinados, inclusive as suas gentes de guerra. Para atingir este fim deveriam destruir as povoações que abrigavam os

50 AHM. Fundo do Governo-geral (séc. XIX). Caixa 8-180. Resenha da Procuradoria da Coroa e Fazenda de Moçambique, de 1898. Ver também ofício do governador dos Territórios da Companhia do Nyassa, de 8 de Junho de 1899, para o governador-geral da Província de Moçambique.

51 AHM. Fundo do Governo-geral (séc. XIX). Caixa 8-180. Ofício do governador dos Territórios da Companhia do Nyassa, de 24 de Novembro de 1898 para o governador-geral de Moçambique.

52 AHM. Fundo do Governo-geral (séc. XIX). Caixa 8-180. Processo referente à expedição ao Niassa. 
revoltosos, arrasar as culturas, tomar o gado, etc. ${ }^{53}$

Não se tratava de uma expedição como as que tiveram lugar até então no interior do Niassa. Na verdade, a "expedição ao Nyassa" foi preparada, segundo as "instruções gerais" de junho de 1899, para ser uma invasão militar portuguesa aos territórios dos chefes yao e a estes associados, a primeira tentativa desta envergadura que iria ser levada a cabo pelos portugueses na região. Manoel de Sousa Machado, major de infantaria, a testa do comando encarregue de uma coluna militar composta de tropas de artilharia, cavalaria e infantaria, entre oficiais e praças europeus e "angolas", auxiliados por 1400 cipais da Maganja da Costa, 500 de Massingire e Marral, 670 dos prazos Mugoro e Goma, 200 do prazo Boror, contando-se 3393 carregadores, deveria efetivamente implantar pontos provisórios de ocupação portuguesa dentro da área da concessão da Companhia do Nyassa, sendo que a administração desta companhia, por sua vez e obrigação, deveria conservar a manutenção dos mesmos. ${ }^{54}$

Até a data os portugueses não haviam fixado qualquer posição militar ou administrativa no Niassa. Até a provável data da morte do sultão Mualia Midala, do Medo, em junho de 1888, as relações entre este sultão e o governador português sediado na vila do Ibo se caracterizaram por idas regulares de embaixadas deste sultão ao Ibo para receber o ordenado estabelecido nos termos de um juramento de vassalagem, ocasiões em que o sultão recebia da parte portuguesa barris de pólvora, espingardas, fazendas, missangas, manteiga, tâmara, cebolas, agulha, linhas de seda, etc. Com a morte deste sultão, sucedeu-lhe seu sobrinho que adota o mesmo nome Mualia e de imediato participa à Ibo que iria continuar a cumprir os termos de vassalagem jurados pelo seu tio e receber os devidos vencimentos. Contudo, em todo o período de 1878 à 1888 apenas dois soldados europeus teriam estado no território do Mêdo. ${ }^{55}$

Sobre as guerras praticadas pelos chefados dos territórios do interior no Distrito de Cabo Delgado, quer as cartas do então falecido sultão Mualia referentes ao período de 1878-1888, quer ainda os ofícios dos capitães-mores de Arimba não fazem referência aos Yao. Ao contrário, referemse aos ataques dos Mafites. Em agosto de 1881 o capitão-mor Caetano José Rezende cita uma informação que recebeu de uma mulher que teria sido aprisionada num ataque dos Mafites contra a povoação de Arimba segundo a qual nesse ataque teriam participado os "mujaos" e os macuas: "Entre os mafites havia mujaus, macuas, e alguns que fallavam a lingua do paiz, supondo-se que

53 AHM. Fundo do Governo-geral (séc. XIX). Caixa 8-180. Instruções gerais para o comandante da expedição ao Nyassa (Processo referente à expedição ao Niassa).

54 Ibid.

55 AHM. Fundo do governo do Distrito de Cabo Delgado (séc. XIX). Caixa 8-8. Cartas do régulo Mualia Midala do Mêdo referentes ao período de 1878-1888. 
estes ultimos são os agarrados nas ultimas invazoes." (sic) ${ }^{56}$

Foi com base em informações das autoridades inglesas em Zomba, Niassalândia, que acabaria por ser projetado o itinerário desta expedição ao Niassa que partiria de Chilomo (quartelgeneral) e seguiria a direção Milange - Mecanhelas - Cuamba - Napulo - Zafari - Mataca - Catuli. O cônsul-geral inglês em Zomba colocou à disposição do governo português o capitão F.B. Pearce, comandante das forças inglesas na Niassalândia, que estaria na posse de mapas de localização dos territórios que deveriam ser alvos da expedição. ${ }^{57}$ Nesse ofício do cônsul-geral inglês transparece que a participação inglesa determinava a estratégia da operação:

[...] your Excellency will agree with me after consideration that it would be a better and quicker course to take that an expeditionary force, after settling the Quamba question, proceed straight to the settlements of Zarafi and Mataka, and, if possible, avoid the necessity of a detour to Fort Johnston until the whole campaign has been finished.

[...] I feel strongly that the subjection of Quamba, Zarafi, and Mataka is no light matter, and yet at the same time it is essential that once the campaign is started it must be carried through speedily and without a check. ${ }^{58}$

Com vista a garantir o êxito desta estratégia, autoridades inglesas em Zomba, Niassalândia, já haviam estabelecido um acampamento militar no lago Chiúta, junto da fronteira entre Moçambique e Niassalândia, composto de uma força de 500 soldados nativos da Niassalândia, 130 tropas indianas, 10 oficiais e um médico ingleses. Garantiam também o abastecimento alimentar e de guerra a partir de companhias inglesas estabelecidas na região. O vice-cônsul inglês em Chinde, em Quelimane, na costa junto ao rio Zambeze, tinha proposto que se acordasse uma ação militar conjunta luso-britânica. ${ }^{59}$

Até 28 de julho de 1899, o capitão Pearce, comandante inglês, já tinha avançado, sem consentimento do Major Machado, as suas forças para a margem oriental do lago Chiúta, interior de

56 AHM. Fundo do governo do Distrito de Cabo Delgado (séc. XIX). Caixa 8-8. Ofício de Caetano José Rezende capitão-mor de Arimba datado de 24 de Agosto de 1881.

57 AHM. Fundo do Governo-geral (séc. XIX). Caixa 8-180. Instruções gerais para o comandante da expedição ao Nyassa. Processo referente à expedição ao Niassa; Telegrama do H.M. Commissioner e cônsul geral da British Central Africa em Zomba de 3 de Julho de 1899 para o governador-geral de Moçambique (Processo referente à expedição ao Niassa).

58 AHM. Fundo do Governo-geral (séc. XIX). Caixa 8-180. Telegrama do H.M. Commissioner e cônsul geral da British Central Africa em Zomba de 3 de Julho de 1899 para o governador-geral de Moçambique (Processo referente à expedição ao Niassa).

59 AHM. Fundo do Governo-geral (séc. xix). Caixa 8-180. Instruções gerais para o comandante da expedição ao Nyassa. In: Processo referente à expedição ao Niassa; Telegrama do H.M. Commissioner e cônsul geral da British Central Africa em Zomba de 3 de Julho de 1899 para o governador-geral de Moçambique; Cópia do telegrama do vice-cônsul britânico em Chinde de 1 de Julho (?) de 1899 (Processo referente à expedição ao Niassa). 
Moçambique. Justificando que se tratava de um procedimento prévio cujo objetivo era abrir a linha de comunicação entre as suas tropas e a marcha das forças da expedição portuguesa que seguiriam em direção ao território do Chefe Cuamba, ao sul do Niassa. Esclarecendo, ainda, que tal procedimento não deveria ser visto como uma intervenção das forças britânicas no território de Moçambique, mas que se encontrava pronto para dar ordens de auxílio e cooperação militar caso o comando português expedisse de forma oficiosa uma carta para o efeito. ${ }^{60}$

A 9 de agosto de 1899, o Major Machado solicita a partir de Mecanhelas, sul do Niassa, que o capitão Pearce ficasse com as suas forças acampado na linha de fronteira no lago Chiúta a fim de proteger o comboio geral da expedição que ficaria acampado em Mecanhelas enquanto ele marchava em avanço para Cuamba. Nessa ocasião, explica que para além deste pedido importante e único não aceitaria sacrifícios da parte britânica nos trabalhos que pertencem unicamente à expedição portuguesa. ${ }^{61}$

\subsection{Combate de Cuamba (23 de agosto de 1899)}

Major Manoel Machado, comandante da expedição ao Niassa, conta que logo depois de retomar sua marcha a partir do acampamento de Mecanhelas a 12 de agosto surgiram os primeiros ataques das forças do Chefe Cuamba contra a coluna da expedição. Tinha sido confiada aos cipais dos prazos, auxiliares da expedição, a tarefa de explorar o terreno para evitar surpresas que eventualmente resultariam em baixas na coluna. Nos dias 14, 20 e 22 de agosto foram registados encontros e tiroteios de pequena envergadura entre as forças do Chefe Cuamba e as forças de avanço da coluna. Em ofício ao governador-geral de Moçambique, Machado conta que no dia 23 de agosto, quando a coluna da expedição atravessava o rio Metanculo junto das povoações periféricas do Chefe Cuamba, teve lugar o mais importante ataque deste chefe africano, emboscando e flanqueando por todos os lados a coluna do Major Machado, e sustentando durante mais de uma hora e meia com bastante pesar a superioridade do armamento da expedição. Só depois de sofrerem bastantes baixas é que as forças do Chefe Cuamba abandonaram as suas povoações e culturas, tendo sido contados pelos portugueses mais de 20 cadáveres abandonados. Só no dia 28 de agosto é que a

60 AHM. Fundo do Governo-geral (séc. XIX). Caixa 8-180. Telegrama de capitão F.B. Pearce, commandant of armed force in British Central Africa de 28 de Julho de 1899 para major Manoel Machado (Processo referente à expedição ao Niassa).

61 AHM. Fundo do Governo-geral (séc. XIX). Caixa 8-180. Ofício do major Manoel Machado de 9 de Agosto de 1899 para capitão F.B. Pearce (Processo referente à expedição ao Niassa). 
coluna da expedição entrou e encontrou abandonadas as povoações principais de Cuamba. Major Machado diz que houve neste combate apenas cinco feridos e três mortos entre os cipais. ${ }^{62}$

Contrariado, Major Machado relata que desde início da expedição ao Niassa a posição efetiva das forças britânicas sob comando do capitão Pearce contrapôs o acordado na conferência de Chilomo entre o governador-geral de Moçambique e o capitão Pearce. Reporta que a 28 de agosto encontrou, com desagrado, uma força do capitão Pearce de 500 a 600 praças africanas nas povoações principais de Cuamba. Machado recorda ao governador-geral de Moçambique que este procedimento já tinha previamente sido objeto de veemente protesto do governador do Distrito da Zambézia. ${ }^{63} \mathrm{O}$ argumento dos ingleses foi de que a ausência de comunicação entre os dois comandos, do Major Machado e do Capitão Pearce, e a suspeita de que poderiam se registrar fortes combates nos domínios do Chefe Cuamba, não deixaram indiferente o Capitão Pearce que avançou julgando haver necessidade de auxílio da parte das forças portuguesas. ${ }^{64}$

A 22 de agosto quando a coluna da expedição se pôs em marcha a partir de Mecanhelas em direção ao território do Chefe Cuamba, o governo britânico em Zomba tinha admitido que, em caso de demora na marcha da coluna portuguesa, iria instruir o comandante Pearce acampado em Chiúta para avançar para o interior do território português contra o Chefe Cuamba com a justificação de evitar uma eventual contra-ofensiva antecipada por parte da força conjunta dos Chefes Cuamba, Mataca e Zarafi. Na ocasião, o governador do Distrito da Zambézia protestou de imediato contra a realização deste procedimento que, segundo o mesmo, violaria os entendimentos da conferência de Chilomo, na qual ficou acordado que a intervenção das forças inglesas deveria ser em prévio acordo com o comando da expedição ao Niassa. Também ficou acordado que não havendo da parte do comando português necessidade de auxílio militar, o avanço das forças sob comando do capitão Pearce no território de Moçambique não só colocaria o receio das duas forças, portuguesas e inglesas, entrarem em conflito no terreno como poderia colocar em perigo os interesses das duas nações europeias. ${ }^{65}$

62 AHM. Fundo do Governo-geral (séc. XIX). Caixa 8-180. Ofício do major Manoel Machado de 8 de Setembro de 1899 para o governador-geral de Moçambique (Processo referente à expedição ao Niassa).

63 AHM. Fundo do Governo-geral (séc. XIX). Caixa 8-180. Ofício do major Manoel Machado de 8 de Setembro de 1899 para o governador-geral de Moçambique (Processo referente à expedição ao Niassa).

64 AHM. Fundo do Governo-geral (séc. XIX). Caixa 8-180. Cópias dos telegramas do H.M. Commissioner e cônsul geral da British Central Africa em Zomba de 22, 23 e 28 de Agosto de 1899, para o governador do distrito de Zambézia em Chilomo; Ofício do major Manoel Machado de 8 de Setembro de 1899 para o governador-geral de Moçambique (Processo referente à expedição ao Niassa).

65 AHM. Fundo do Governo-geral (séc. XIX). Caixa 8-180. Cópia do telegrama do H.M. Commissioner e cônsul geral da British Central Africa em Zomba de 22 de Agosto de 1899 para o governador do distrito de Zambézia em Chilomo; Cópia do telegrama do governador do distrito da Zambézia de 23 de Agosto de 1899 para H.M. Commissioner e cônsul geral da British Central Africa em Zomba (Processo referente à expedição ao Niassa). 
O governador do Distrito da Zambézia chegou mesmo a solicitar a imediata ocupação efetiva da faixa fronteiriça com a Niassalândia em Chiúta entre o lago Niassa e Amaramba, tendo até colocado seu lugar a disposição de tão contrariado pelos ultimatos e contra-argumentos contra o seu protesto demonstrados pelo comissário e cônsul geral britânico em Zomba. ${ }^{66}$ No seu telegrama de 23 de agosto enviado ao governador do Distrito da Zambézia, o comissário e cônsul britânico em Zomba expôs nos seguintes termos a posição inglesa em relação a expedição ao Niassa:

I must however ask your excellency to give me definite and absolute assurance firstly that the whole campaign will be at once energically carried out and finished before the rains and secondly that portuguese government will be responsible for all losses to british subjects caused by the raids hencefort the campaign not be successfull. I shall on receiving that assurance withdraw all british troops from the frontier and take no further action it is impossible for the british force to remain longer in its present anomalous position. ${ }^{67}$

Pouco depois em setembro deste ano de 1899 quando preparava o acampamento em Napulo, sul do Niassa, para servir de base de operações desta vez contra o Chefe Mataca, Machado volta a lamentar o cometimento britânico em relação aos entendimentos de Chilomo sobre a expedição ao Niassa. Tenente C. Percival, comandante britânico do forte de Mangoche, em Niassalândia, tinha notificado aos portugueses que não seria permitida a passagem de nenhum soldado ou auxiliar armado das forças portuguesas da expedição transitar por este território em direção a Napulo. Entendendo que a escolta dos comboios de carregadores da expedição portuguesa deveria ser feita apenas pela força britânica e que a entrada de qualquer comboio de carregadores para dentro do protetorado britânico deveria previamente ser notificada e a sua escolta mantida sob seu comando ou outro oficial britânico por si indicado. ${ }^{68}$

O governador da Zambézia e o Major Machado classificaram este incidente como reflexo de um eventual mal-entendido e excesso de zelo da parte do Tenente Percival. O governador do Distrito da Zambézia solicita ao governador-geral de Moçambique para que recordasse ao governo do protetorado britânico da Niassalândia que este facto representava a denegação de licença anteriormente concedida pelo comissário britânico em Zomba a 1 de setembro e que ao suceder

66 AHM. Fundo do Governo-geral (séc. XIX). Caixa 8-180. Ofício do governador do distrito da Zambézia de 24 de Agosto de 1899 para o governador-geral de Moçambique (Processo referente à expedição ao Niassa).

67 AHM. Fundo do Governo-geral (séc. xix). Caixa 8-180. Cópia do telegrama do H.M. Commissioner e cônsul geral da British Central Africa em Zomba de 23 de Agosto de 1899 para o governador do distrito de Zambézia em Chilomo (Processo referente à expedição ao Niassa).

68 AHM. Fundo do Governo-geral (séc. xix). Caixa 8-180. Cópia do telegrama de C. Percival, liutenent rifle brigade officer commanding Fort Mangoche, de 10 de Setembro de 1899 (Processo referente à expedição ao Niassa). 
como exposto pelo referido tenente inglês o facto representaria a quebra do acordo de Chilomo. Recordando ainda aos ingleses que a campanha em curso era "emprehedida unicamente por attenção as suas reclamações e que a falta do seu apoio destroe os sacrificios feitos e o seu principal objectivo". 69

Fora as lamentações, o Major Machado pôde contar que os combates havidos no território do Chefe Cuamba resultaram na implantação do posto militar de Napulo, na povoação com o mesmo nome situada na margem oriental do lago Amaramba, Niassa, a 28 de setembro de 1899. O posto recebeu o nome de forte D. Carlos I. ${ }^{70}$

\subsection{Combate de Muembe (19 de outubro de 1899)}

Pouco depois da coluna militar da expedição atravessar o rio Luambala, na margem esquerda do rio Lugenda, na manhã de 16 de outubro as forças do Chefe Mataca tentaram sem êxito impedir a marcha e cortar o avanço das forças portuguesas. Para o Chefe Mataca a ameaça se tornaria eminente caso as suas forças não sucedessem em impedir as forças inimigas de atravessar mais duas barreiras naturais, os rios Namatanda e Luangua, em direção à sua capital Muembe. Entretanto, a 19 de outubro a coluna militar da expedição sucede ao vencer aquilo que o Major Machado classificou de "pertinaz resistência" pela defesa da cidade do Chefe Mataca. Depois da invasão da capital do Chefe Mataca, Muembe, as forças de Machado queimaram quatrocentas e trinta e sete palhotas abandonadas. ${ }^{71}$

Machado calcula que o Chefe Mataca tenha reunido cerca de cinco mil combatentes armados e não armados. Na sua cidade, Muembe, foram contadas cerca de 4837 casas de construção sólida e comodidade "relativa". Depois de destruir a cidade de Muembe, a coluna do Machado seguiu o caminho pelas povoações abandonadas de Chichuma, irmão do Chefe Mataca, em direção ao território do Chefe Zarafi. Entre os dias 24 e 30 de outubro a força expedicionária acampou na margem esquerda do rio Luangua aguardando que o Chefe Mataca se rendesse aos portugueses para "pegar pé", aceitando deste modo a proposta feita pelo Machado para o fim da guerra e das

69 AHM. Fundo do Governo-geral (séc. XIX). Caixa 8-180. Ofício do governador do distrito da Zambézia de 25 de Setembro de 1899; Ofício do major Machado de 16 de Setembro de 1899; Cópia do telegrama do H.M. Commissioner e cônsul geral da British Central Africa em Zomba de 1 de Setembro de 1899 (Processo referente à expedição ao Niassa).

70 AHM. Fundo do Governo-geral (séc. XIX). Caixa 8-180. Ofício de major Machado de 28 de Setembro de 1899 para o governador do distrito da Zambézia (Processo referente à expedição ao Niassa).

71 AHM. Fundo do Governo-geral (séc. XIX). Caixa 8-180. Cópia do telegrama do major Machado de 9 Novembro de 1899 [calculando que o telegrama foi enviado na data de chegada da coluna em Napulo] para o governador da Zambézia; relato do major Machado de 28 de Novembro de 1899 (Processo referente à expedição ao Niassa). 
destruições. No seu relato Machado conta que, quando a sua coluna militar avançava a caminho das povoações do Chefe Zarafi, o Chefe Mataca teria enviado uma carta declarando reconhecer os portugueses como "senhores dos terrenos", afirmando que se encontrava foragido no mato com os seus "grandes e mulheres", não tendo culpa do mal que teria sido cometido pelos seus parentes já falecidos; portanto, pedia que não queimassem mais as povoações, nem matassem mais gente e que o deixassem cultivar as suas terras. ${ }^{72}$

As forças portuguesas da expedição foram então recebidas pelo Chefe Zarafi, com quem teriam previamente avançado termos de um pré-acordo, ao fim não realizado, segundo os quais este chefe aceitaria ser desterrado pelos portugueses acompanhado pelo seu povo para qualquer parte dos domínios portugueses onde estariam ao abrigo das investidas dos ingleses e do Chefe Mataca. A 3 de novembro, a coluna retirou-se para o posto militar de Napulo, de onde regressou para Milange, de volta ao Distrito da Zambézia, com a justificação de que aproximava a época das chuvas e escasseavam os mantimentos da expedição. Ao fim da expedição contava-se um saldo de destruições e mortes, 3410 prisioneiros feitos nas povoações do Chefe Mataca e mais de mil das povoações do Chefe Zarafi, incluindo a mãe deste. Tendo sido destruída a capital Muembe, símbolo do prestígio, do esplendor, da riqueza e grandeza do Estado do Mataca. Para além disso, os portugueses parecem ter ganho a aproximação dos Chefes Zarafi, Cuirassia e Metarica. ${ }^{73}$

No ofício do governador do Distrito da Zambézia não consta o conteúdo das cartas e a finalidade da ponta de marfim que segundo o telegrama do Tenente Albano Morais, do posto militar de Napulo, enviado àquele governador, os emissários dos Chefes Zarafi e Metarica levaram a este posto. $\mathrm{O}$ facto foi interpretado como sendo manifestação de disposição desses chefes a coadjuvar a coluna contra o Chefe Mataca. ${ }^{74}$

O cónego do concelho de Tungue, Cabo Delgado, em novembro deste ano comunicou as informações obtidas por africanos vindos de Mikindane, África Oriental Alemã (Tanganyika), segundo as quais o Chefe Mataca mandara provavelmente em outubro cartas ao comandante militar do posto de Mikindane "provavelmente" a pedir que os alemães o recebessem no seu território no caso em que se visse forçado a sair das suas terras. Nessa ocasião, o governador-geral de Moçambique solicitara ao governador da Companhia do Nyassa no Ibo que era de toda a

72 AHM. Fundo do Governo-geral (séc. XIX). Caixa 8-180. Relato do major Machado de 28 de Novembro de 1899 (Processo referente à expedição ao Niassa):

73 AHM. Fundo do Governo-geral (séc. XIX). Caixa 8-180. Relato do major Machado de 28 de Novembro de 1899 (Processo referente à expedição ao Niassa); para os números indicados ver cópia do telegrama do major Machado de 9 Novembro de 1899 [calculando que o telegrama foi enviado na data de chegada da coluna em Napulo] para o governador da Zambézia (Processo referente à expedição ao Niassa).

74 AHM. Fundo do Governo-geral (séc. XIX). Caixa 8-180. Ofício do governador distrital da Zambézia de 27 de Outubro de 1899 para o governador-geral de Moçambique (Processo referente à expedição ao Niassa). 
conveniência tratar de saber o paradeiro do Chefe Mataca, a fim de se proceder à sua captura pelos “agravos e depredações” em território do protetorado britânico da África Central, Niassalândia. ${ }^{75}$

Pouco antes da "expedição ao Nyassa" ser dissolvida a 12 de dezembro de 1899 pelo governador-geral de Moçambique ${ }^{76}$ desembarcou em Ibo a 1 de dezembro deste ano, tendo saído em outubro de Lisboa, a expedição preparada pela Companhia do Nyassa com a finalidade de assegurar a ocupação portuguesa no posto militar de Napulo e manter o estado das disposições favoráveis dos demais chefes da região do Niassa. Esta expedição acabaria por aguardar em Pemba a chegada de carregadores enviados pelo Chefe Metarica, mantimentos e treinos necessários para adestrar os soldados no manejo das armas e dos muares para a tração da cavalaria pelo interior. ${ }^{77}$

Até ao fim do século XIX, era de forma indireta que as autoridades da Companhia do Nyassa no Ibo tomavam conhecimento do curso da situação na região do Niassa. Ao oeste do rio Lugenda tinha sido instalado apenas o forte D. Carlos I em Napulo. O governador da Companhia do Nyassa no Ibo, João M. Guerreiro d'Amorim, reporta que recebeu a 23 de novembro de 1898 ordens de Lisboa para estabelecer um posto militar no Niassa, junto da fronteira entre o território da concessão e o protetorado inglês da Niassalândia. Ele arrola inúmeras dificuldades de ordem natural para a execução imediata desta ordem. Aponta que se encontrava em época das chuvas e porque era também a época das sementeiras, haveria pouca disponibilidade de reunir cerca de 400 a 500 carregadores para a condução de material de guerra (que na altura seria necessária para assegurar a penetração até ao interior do Niassa, dado que seria a primeira incursão do género), e de condução de material de construção, mantimentos, fazendas, e outras necessidades para a organização de uma expedição para o Niassa. Para além de que a época das chuvas, os numerosos cursos de água e as poças existentes na região tornariam intransitável o caminho a percorrer. Concluindo que não existindo qualquer estação no interior que pudesse servir de abrigo e se encontrar recursos para os oficiais, sargentos, cabos e soldados, a época não era de todo propícia para se obter algum êxito. ${ }^{78}$

\subsection{Primeiros postos militares no Niassa}

75 AHM. Fundo do Governo-geral (séc. XIX). Caixa 8-180. Ofício do governador dos Territórios da Companhia do Nyassa, de 15 de Novembro de 1899 para o governador-geral de Moçambique.

76 AHM. Fundo do Governo-geral (séc. XIX). Caixa 8-180. Portaria do governador-geral de Moçambique de 12 de Dezembro de 1899; Ofício do governador dos Territórios da Companhia do Nyassa, de 2 de Dezembro de 1899 para o governador-geral de Moçambique.

77 AHM. Fundo do Governo-geral (séc. XIX). Caixa 8-180. Ofício do governador dos Territórios da Companhia do Nyassa, de 2 de Dezembro de 1899 para o governador-geral de Moçambique.

78 AHM. Fundo do Governo-geral (séc. XIX). Caixa 8-180. Ofício do governador dos Territórios da Companhia do Nyassa, de 24 de Novembro de 1898 para o governador-geral de Moçambique. 
Logo após as invasões perpetradas pela expedição ao Niassa comandada pelo major Manoel Machado a preocupação passou a ser a necessidade de implantação da estrutura administrativa na região, que implicava a criação de denominações coloniais que politicamente sobreporiam as divisões territoriais africanas. Os concelhos e circunscrições deveriam ser chefiados por administradores de concelho e de circunscrição, respetivamente e os postos por chefes de postos. Partia-se do princípio que a criação dessas instituições teria impacto psicológico nas povoações, submetendo-as à conformação diante da autoridade colonial portuguesa.

Para além do terror das destruições e mortes, em termos efetivos a "expedição ao Nyassa" foi apenas ao ponto de suceder na implantação do forte denominado D. Carlos I e dois baluartes denominados Eduardo Villaça e Álvaro Ferreira a 28 de setembro de 1899, na povoação de Napulo situada na margem oriental do lago Amaramba. Para o major Machado o posto militar de Napulo desempenharia um papel estratégico pela sua posição próxima aos fortes ingleses de Johnston e Mangoche na Niassalândia, para além de que sua localização seria ideal para apoiar e abastecer a coluna da "expedição ao Nyassa" na marcha contra o Mataca e para servir de quartel à força de ocupação portuguesa. ${ }^{79}$

Quando a expedição do major Machado retirou-se para Milange, Distrito da Zambézia, ficou em Napulo, José Bernardo Dias como comandante interino do posto que deveria com o material de guerra deixado cumprir a missão de manter as boas relações e obstar incursões e ataques de retaliação por parte dos Chefes Mataca e Cuamba ou qualquer outro chefe até que a Companhia do Nyassa ocupasse o Niassa. ${ }^{80}$

Passados cerca de um ano após o término da expedição contra o Mataca, em dezembro de 1900, sem registro de que teria havido algum combate, uma pequena força da Companhia do Nyassa comandada pelo tenente João dos Santos Pires Viegas, composta de 54 praças europeias e 90 soldados africanos e um médico, tendo saído de Quissanga atravessou a margem esquerda do rio Lugenda e ergueu o posto militar denominado D. Luis Filipe e um outro em Iaparata, ambos no território do Metarica. ${ }^{81}$

79 AHM. Fundo do Governo-geral (séc. XIX). Caixa 8-180. Ofício de major Machado de 28 de Setembro de 1899 para o governador do distrito da Zambézia (Processo referente à expedição ao Niassa).

80 AHM. Fundo do Governo-geral (séc. XIX). Caixa 8-180. Ofício de José Bernardo Dias comandante interino no forte D. Carlos I de 12 de Novembro de 1899; ofício do governador da Zambézia de 12 de Dezembro de 1899 para o governador-geral de Moçambique; instruções do major Machado de 11 de Novembro de 1899 ao comandante interino José B. Dias (Processo referente à expedição ao Niassa).

81 AHM. Fundo do Governo-geral (séc. xix). Caixa 8-180. Ofício de João dos Santos Pires Viegas de 8 de Dezembro de 1900 ao intendente do governo no Ibo (Processo referente à expedição ao Niassa). 


\section{Considerações finais}

Pode-se observar que as resistências dos chefes africanos foram de modalidades diferentes visando em última instância a preservação da sua autoridade política e territorial face ao novo contexto histórico que afetou a região oriental e central da África. Nesta perspetiva, a posição diferenciada, consubstanciada em acordos de aproximação e redução de tensões, demonstrada pelo Metarica, Zarafi, Cuirassia, Mualia Midala entre outros importantes chefes africanos foi também uma modalidade a ter em conta na resistência contra a invasão militar colonial na história de Moçambique.

\section{Referências Bibliográficas:}

\section{AHM. Fundo do Governo do Distrito de Cabo Delgado (séc. XIX):}

Caixa 8-36. Ordem do dia ${ }^{\circ} 14$ do governador-geral de Moçambique (de 8 de Junho de 1840).

Caixa 8-8. Ofício de Diogo José Fernandes, sargento-mor de Amiza, para o governador das Ilhas de Cabo Delgado (de 27 de Janeiro de 1849).

Caixa 8-8. Ofício de Luciano Policarpo de Souza, capitão-mor de Amiza, datado de 31 de Agosto de 1858, para o governador do distrito de Cabo Delgado.

Caixa 8-36. Ofício do diretor das obras públicas de Moçambique para o governador de Cabo Delgado (de 2 de Dezembro de 1881).

Caixa 8-36. Ofícios do governador-geral de Moçambique ao comandante da divisão naval d'África e mar da Índia; Esboço de instruções dadas ao comandante da canhoneira „Quanza“ em comissão a desempenhar na costa norte de Moçambique (de 13 e 14 de Janeiro de 1886).

Caixa 8-36. Ofício do comandante da canhoneira „Vouga“ ao governador do distrito de Cabo Delgado (de 30 de Janeiro de 1886).

Caixa 8-36. Ofício de Augusto Cardoso subchefe encarregado da expedição „Pinheiro Chagas“ ao governador do distrito de Cabo Delgado (de 18 de Dezembro de 1885).

Caixa 8-36. Auto de vassalagem do Metarica (de 16 de Dezembro de 1885) e o de Cuirassia (de 20 de Janeiro de 1886).

Caixa 8-36. Ofício de Luiz Augusto Machado Leal encarregado da „missão civilizadora ao lago Nyassa“" ao governador do distrito de Cabo Delgado (de 11 de Junho de 1889).

Caixa 8-36. Termo de vassalagem do régulo Cuirassia (de 11 de Junho de 1889). 
Caixa 8-36. Ofício de José Gonçalves Barriga, comandante da missão Mariano de Carvalho (expedição ao Lugenda e sul do Rovuma), ao governador do distrito de Cabo Delgado (de 16 de Junho de 1891).

Caixa 8-16. Ofício da Companhia do Nyassa no Ibo para o governador de Cabo Delgado (de 26 de Dezembro de 1893).

Caixa 8-16. Ofício de H. Copeland general-manager e diretor em África para a Companhia do Nyassa para o governador do distrito de Cabo Delgado (de 13 de Junho de 1894).

Caixa 8-16. Ofício de Arthur C. Wheatley administrador da Companhia do Nyassa para o governador do distrito de Cabo Delgado (de 10 de Julho de 1894).

Caixa 8-8. Cartas do régulo Mualia Midala do Mêdo referentes (de 1878-1888).

Caixa 8-8. Ofício de Caetano José Rezende capitão-mor de Arimba (de 24 de Agosto de 1881).

\section{AHM. Fundo do Governo-geral (séc. XIX):}

Caixa 8-31. Correspondências dos governadores das Ilhas de Cabo Delgado ao Governador e Capitão General de Moçambique (de 1824-1830).

Caixa 8-31. Ofício do Governador das Ilhas de Cabo Delgado José António Caldas ao Governador e Capitão General de Moçambique (de 2 de Março 1824).

Caixa 8-31. Correspondências do governador das Ilhas de Cabo Delgado ao governador-geral de Moçambique (de 25 de Março de 1854).

Caixa 8-31. Correspondência do capitão-mor e comandante de Amiza ao governador das Ilhas de Cabo Delgado (de 24 de Março de 1854).

Caixa 8-31. Tradução da carta de Bacar Muchamo residente em Mineguene (de 16 de Março de 1854).

Caixa 8-31. Correspondência do governador das Ilhas de Cabo Delgado datado de 30 de Agosto de 1854 e demais correspondências sobre o assunto incluindo a declaração do capitão do "Grognard" (30 de Agosto de 1854).

Caixa 8-31. Correspondência do patrão-mor do porto de Ibo ao governador das Ilhas de Cabo Delgado (24 de Outubro de 1854).

Caixa 8-31. Correspondência do governador das Ilhas de Cabo Delgado para o governador-geral da Província de Moçambique (de 9 de Dezembro de 1856).

Caixa 8-31. Ofícios do governador das Ilhas de Cabo Delgado para o régulo Mugabo (de 27 Outubro e 12 de Novembro de 1857).

Caixa 8-31. Carta do Régulo Mugabo ao governador das Ilhas de Cabo Delgado (de 17 de Novembro de 1857). 
Caixa 8-31. Termo de relações entre o governo português no Ibo e o régulo Mugabo, datado de 17 de Novembro de 1857.

Caixa 8-31. Termo de constituição da colónia (de 8 de Dezembro de 1857).

Caixa 8-179. Ofício do diretor da Alfândega do Distrito de Cabo Delgado (9 de Dezembro de 1881).

Caixa 8-179. Ofício do diretor da alfândega do Ibo para o governador-geral de Moçambique (de 10 de Dezembro de 1887).

Caixa 8-151. Cópia do ofício do governador-geral de Moçambique João de Tavares de Almeida, que acompanhou o tratado de amizade e comercio com o sultão de Zanzibar (de 8 de Fevereiro de 1862).

Caixa 8-151. Cópia do ofício de Francisco Maria da Cunha plenipotenciário na assinatura do tratado de amizade e comércio com Zanzibar (de 1 de Dezembro de 1879).

Caixa 8-151. Ofício de Gregório José Ribeiro (de 27 de Junho de 1883).

Caixa 8-179. Ofício do intendente do governo no Ibo ao governador-geral da Província de Moçambique (de 21 de Dezembro de 1894).

Caixa 8-179. Ofício do intendente do governo interino no Ibo ao governador-geral da Província de Moçambique (de 9 de Julho de 1896).

Caixa 8-179. Ofício do intendente do governo interino no Ibo ao governador-geral da Província de Moçambique (de 20 de Agosto de 1896).

Caixa 8-179. Ofício do governador do Território da Companhia do Nyassa ao intendente do governo no Ibo (de 24 de Julho de 1896).

Caixa 8-179. Ofício do intendente do governo no Ibo ao governador-geral da Província de Moçambique (de 27 de Julho de 1896).

Caixa 8-180. Ofício do governador dos Territórios da Companhia do Nyassa para o governador-geral da Província de Moçambique (de 8 de Junho de 1898).

Caixa 8-180. Cópia do ofício de 6 de Junho de 1898 do Senhor Loynes d'Anteroche feita no governo dos Territórios da Companhia do Nyassa no Ibo e enviada ao governador-geral de Moçambique (de 8 de Junho de 1898).

Caixa 8-180. Resenha da Procuradoria da Coroa e Fazenda de Moçambique de 1898.

Caixa 8-180. Ofício do governador dos Territórios da Companhia do Nyassa para o governador-geral de Moçambique (de 24 de Novembro de 1898).

Caixa 8-180. Processo referente à expedição ao Niassa.

MINISTÉRIO DA MARINHA E ULTRAMAR. Companhia do Nyassa: Decretos, Portarias, Regulamentos e Mais Diplomas relativos a esta companhia. Lisboa: Imprensa Nacional, 1897. 
Sankofa. Revista de História da África e de Estudos da Diáspora Africana Ano IX, NXVIII, dezembro/2016

Recebido em 19/04/2016 - Aprovado em 27/07/2016 